\title{
Biting off More Than They Can Chew? The Impact of Pedagogical Application of Corpus on Vocabulary Ability of Intermediate-Level ESL Learners in Mainland China: A Quasi-Experimental Study
}

\author{
Jing Shi ${ }^{1,2}$ \\ 1 School of English for International Business, Guangdong University of Foreign Studies, Guangzhou, \\ Guangdong, China \\ ${ }^{2}$ English Department, Faculty of Arts and Humanities, University of Macau, Macau, China \\ Correspondence: Jing Shi, School of English for International Business, Guangdong University of Foreign \\ Studies, Guangzhou, Guangdong, 510420, China. E-mail: sj@oamail.gdufs.edu.cn
}

Received: July 31, 2017 Accepted: August 20, $2017 \quad$ Online Published: August 23, 2017

doi: 10.5539/elt.v10n9p232 URL: http://doi.org/10.5539/elt.v10n9p232

\begin{abstract}
The pedagogical values of corpora for ELT have been widely acknowledged and exploited, but their direct application in classroom teaching has entailed many difficulties. This project aims to investigate the impact of the pedagogical application of corpora on the vocabulary ability of intermediate-level ESL learners in mainland China. This quasi-experimental research study was conducted primarily using pretests and posttests of vocabulary knowledge with one experimental group and one control group of 15 respondents in each group, respectively. Findings indicate that the pedagogical application of a corpus with adequate instruction is more effective and efficient in improving learners' vocabulary. It is hoped that this research can contribute significantly to the education of ESL learners within the Chinese context by promoting more informed, curious, and critical engagement through English lexical learning.
\end{abstract}

Keywords: pedagogical application of corpus, ELT, lexical awareness

\section{Introduction}

The pedagogical application of corpora is meant to resolve some known lexical teaching and acquisition difficulties commonly experienced by ESL teachers and learners. This research aims to evaluate the impact of the corpus-based teaching and learning approach in order to increase the effectiveness of ESL lexical teaching and learning in the Chinese context.

The new General Service List (new-GSL) is applied in the pedagogical process and in the analytical research of this project. The new-GSL is a robust comparison of four language corpora (LOB, BNC, BE06, and EnTenTen12) of a total size of over 12 billion running words, compiled by Brezina and Gablasova (Brezina et al., 2015). The teaching materials used in the experimental group are selected and edited by manipulating the new-GSL. The pretest and posttest are designed by using the new-GSL. The collected data will be analyzed and hopefully the result can reveal new findings concerning the impact of the pedagogical application of the corpus on the vocabulary of intermediate-level ESL learners in mainland China. The pedagogical application of corpus linguistics is an untapped field for ESL teaching in mainland China, and it is hoped that this research can narrow the gap between theory and practice, with the results of this research actually impacting what happens in the ESL classroom.

\section{Brief theoretical Basis}

Barkley (2009) pointed out the importance of engagement in teaching and learning in higher education. Engaged students have a passion and excitement for learning and they are motivated and eager to make meaning of what they are learning. Edgerton (qtd. in Barkley, 2009) proposed several ground rules for engaged teaching approaches, such as problem-based learning, collaborative learning, and undergraduate research. Bowen (qtd. in Barkley, 2009) further indicated that these rules were all based on one vital principle: learning by doing. Once students are required to "do" the task, they are involved in the learning process. Bernardini's (2002) philosophy of "learner as traveler" and John's (1991) "learner as researcher" coincide with the "learning by doing" principle, 
and the pedagogical application of corpora is a problem-based learning process that requires both collaborative learning and undergraduate research.

The pedagogical application of corpora, which is often neglected by ESL teachers, in fact, has a vital role to play. The work by Thurstun and Candlin (1998) emphasized the value of concordancing in the development of teaching materials focusing on vocabulary and grammar as well as the line between them. Kennedy's (2003) study revealed the importance of corpus-based collocation teaching in the language teaching curriculum. Ellis et al. (2008) illustrated the significance of the pedagogical application of corpora in formulaic language teaching for ESL learners, especially for English for Academic Purposes (EAP). Stubb (1996) stated that the boundary between vocabulary and grammar is blurred, and that it is not necessary to put them in binary positions as they are entwined. Furthermore, Michael Lewis's (2002) groundbreaking lexical approach, fundamentally revised the way in which we perceive language, viewing language as lexis rather than as vocabulary and grammar. The pedagogical application of corpora is grounded in this theory.

The pedagogical application of corpus was welcomed by students and teachers but it also encountered many difficulties (Cheng et al., 2003). Facilitation from teachers was proved to be of great significance, but questions arose: How much facilitation do students need? What support is necessary for students in the pedagogical application of the corpus? How should the pedagogical application of the corpus be modified or improved?

Flowerdew (2009) reviewed and discussed the four controversial aspects of the pedagogical application of corpora and offered concrete suggestions for avoiding pitfalls and modifying the method. The four aspects include 1) the combination of the bottom-up and top-down fashion, 2) pedagogical mediation for revealing the embedded context, 3) the intervention of teachers, and 4) the use of a suitable corpus. The pedagogical application of a corpus in this research has been improved in terms of these four aspects. Other experts have also pointed out the direction for the development of pedagogical application of corpus. There are two general L2 lexical teaching approaches: one is the word association approach, with the meaning of words and their L1 translation being imparted to learners; the other is the contextualized approach, emphasizing the learning of L2 words in context (Jiang, 2000). The contextualized approach encourages the inference of meaning and attempts to minimize learners' reliance on L1. This approach seems to be more effective for the development of learners' L2 lexical competence (Jiang, 2000). The pedagogical application of corpora is part of the contextualized method. Corpus application in the classroom is categorized as being of two types: indirect and direct (Romer, 2006). Indirect application can be quite successful, but the direct use of a corpus in classroom teaching has gives rise to many difficulties. Romer (2011) claimed that fostering direct uses of corpora in L2 learning and focusing on learner and teacher needs are two important topics for future development. The application of corpora in this research meets these two requirements.

\section{Research design and Methods}

\subsection{Hypotheses}

The participants fall into two groups. Participants in Group A (the experimental group) are exposed to a large quantity of language data that are edited by instructors via the application of the new-GSL. The teaching process is implemented in a combination of top-down and bottom-up styles. The target lexical items are displayed in the KWIC format. The participating learners, in the mode of Observe-Hypothesize-Experiment (OHE), observe the language data, hypothesize the lexical use, report their hypothesis to the whole class, and finally find out the correct ways of using the target words. Participants in Group B (the control group) acquire lexical knowledge through the conventional method, in which relevant lexical information is imparted directly to them. The study attempts to answer the following research questions:

1) Are there any significant differences between the two groups' vocabulary after the two different types of instruction have been implemented for one academic semester?

2) To what extent can the difference be explained with regard to the different teaching methods?

The hypotheses in relation to these research questions are as follows:

HØ: There are no differences between the two groups' vocabulary ability.

H1: The experimental group outperforms the control group in vocabulary ability. The pedagogical application of a corpus along with adequate instruction is more suitable for improving learners' vocabulary ability.

H2: The control group outperforms the experimental group in vocabulary ability. The conventional method is better than the innovative pedagogical application of a corpus in enhancing learners' vocabulary ability. 


\subsection{Methodology}

This research mainly investigates the effects of the pedagogical application of a corpus (the independent variable) on ESL learners' vocabulary ability (the dependent variable). The other variables should be tightly controlled in order to ensure the validity and reliability of the research (Mackey et al., 2005). The reason it is referred to as a quasi-experiment rather than a true experiment is that the assignment of respondents into experimental and control group is not random but "naturally given" (Rasinger, 2013). Methodological triangulation (Mackey et al., 2005), using multiple measures and combining quantitative and qualitative methods, is applied in this research. The purpose of applying methodological triangulation in this investigation is to yield more convincing and persuasive results. The strengths of methodological triangulation or mixed method research, as Dornyei (2007) pointed out, include the following: 1) the quantitative and qualitative methods can mutually reinforce each other, 2) the mixed-method approach is particularly appropriate for multi-level analysis of complex issues, 3) the mixed-method approach improves the validity of the research, and 4) the mixed method approach can reach multiple audiences. However, the other side of this is that methodological triangulation is not a panacea, and both Angouri (2010) and Dornyei (2007) illustrated the weakness of a mixed-method approach. When being adopted in research, methodological triangulation should be handled with caution. As long as it is carefully planned, the mixed-method approach can usually offer additional benefits for the understanding of a particular phenomenon and the answering of research questions.

\subsection{Setting and Participants}

The quasi-experiment is conducted in a university in south China renowned for its ESL teaching and learning. The 30 participants are English majors, first-year college students, and they are informed of the purpose of the study. They fill out bio-data forms and complete both a Paul Nation vocabulary size test (http://www.victoria.ac.nz/lals/about/staff/paul-nation (accessed on 2/8/2017)) and TOEFL to ensure participants in the two groups are of identical English proficiency level and vocabulary sizes and of similar backgrounds. The outliers are dismissed. The homogeneity of participants is beneficial for the generalization of the research results, but it necessarily leads to a narrowing in the scope of the research.

\subsection{Testing Measures and Administration}

Cobb's (1997) study pointed out the difficulties of evaluating the effects of pedagogical application of corpus on learners. Since there is no one-size-fit-all approach to assessing the effects of pedagogical application of corpora on learners, and this research does not necessarily to answer all the questions concerning the pedagogical application except for the research questions, the testing measures, based on Chapelle's concept of vocabulary ability, is innovatively designed and applied. The tests and tasks are implemented to evaluate learners' vocabulary ability in two aspects: the context of vocabulary use and vocabulary knowledge.

In terms of assessing the context of vocabulary use and vocabulary knowledge, both a pretest and posttest of reading comprehension exercises are used. In the reading comprehension section, the two articles for pretest and posttest are of similar word count, selected from the same domain, and evaluated by the new-GSL. The articles should be selected only if they are of similar lexical difficulty. The items for tests have the same pattern: a focus-on-form question type simply requires learners to remember which of two words is used in the article, with each pairing having a similar form or meaning. A focus-on-meaning question type asks participants to choose the best translation of a word from the text. The qualitative method is applied to triangulate the testing results, aimed at identifying the effects of the pedagogical application of corpus on intermediate-level ESL students in mainland China.

\subsection{Data Collection and Analysis}

Both the quantitative data of pretest and posttest and the qualitative data of pretest and posttest are collected within the classroom by the researcher, who has not been involved in the teaching and learners' academic assessment. The lexical complexity of the two articles for pretest and posttest are evaluated by the new-GSL, and the results indicate that the two articles are of similar lexical complexity, as illustrated in the following tables. 
Table 1. Results of article used for pretest

\begin{tabular}{ll}
\hline Sentences analyzed & 22 \\
\hline Words analyzed & 516 \\
Words covered by the new-GSL & $432(83.72 \%)$ \\
New-GSL 500 & $311(60.3 \%)$ \\
New-GSL 1000 & $49(9.5 \%)$ \\
New-GSL 2500 & $72(14 \%)$ \\
Off list & $84(16.3 \%)$ \\
\hline
\end{tabular}

Table 2. Results of article used for posttest

\begin{tabular}{ll}
\hline Sentences analyzed & 32 \\
\hline Words analyzed & 462 \\
Words covered by the new-GSL & $387(83.77 \%)$ \\
New-GSL 500 & $286(61.9 \%)$ \\
New-GSL 1000 & $39(8.4 \%)$ \\
New-GSL 2500 & $62(13.4 \%)$ \\
Off list & $75(16.2)$ \\
\hline
\end{tabular}

Table 3. Lexical complexity of article used for pretest

\begin{tabular}{lllllll}
\hline NOUNS & 144 & 33 & 19 & 51 & 41 & $103(71.53 \%)$ \\
\hline VERBS & 95 & 66 & 10 & 5 & 14 & $81(85.26 \%)$ \\
MODALS & 3 & 3 & 0 & 0 & 0 & $3(100 \%)$ \\
ADJECTIVES & 63 & 10 & 14 & 13 & 26 & $37(58.73 \%)$ \\
ADVERBS & 28 & 19 & 3 & 3 & 3 & $25(89.29 \%)$ \\
CONNECTORS (prepositions \& conjunctions) & 76 & 73 & 3 & 0 & 0 & $76(100 \%)$ \\
PRONOUNS & 14 & 14 & 0 & 0 & 0 & $14(100 \%)$ \\
OTHER (gram. words) & 93 & 93 & 0 & 0 & 0 & $93(100 \%)$ \\
\hline
\end{tabular}

Table 4. Lexical complexity of article used for posttest

\begin{tabular}{lllllll}
\hline NOUNS & 134 & 31 & 18 & 41 & 44 & $90(67.16 \%)$ \\
\hline VERBS & 92 & 59 & 11 & 11 & 11 & $81(88.04 \%)$ \\
MODALS & 3 & 3 & 0 & 0 & 0 & $3(100 \%)$ \\
ADJECTIVES & 41 & 11 & 6 & 7 & 17 & $24(58.54 \%)$ \\
ADVERBS & 28 & 21 & 1 & 3 & 3 & $25(89.29 \%)$ \\
CONNECTORS (prepositions \& conjunctions) & 64 & 62 & 2 & 0 & 0 & $64(100 \%)$ \\
PRONOUNS & 28 & 28 & 0 & 0 & 0 & $28(100 \%)$ \\
OTHER (gram. words) & 72 & 71 & 1 & 0 & 0 & $72(100 \%)$ \\
\hline
\end{tabular}

The collected data of pretests for both the control group and the experimental group are analyzed by SPSS 24 . The normal distribution of data is illustrated in the following figure. 

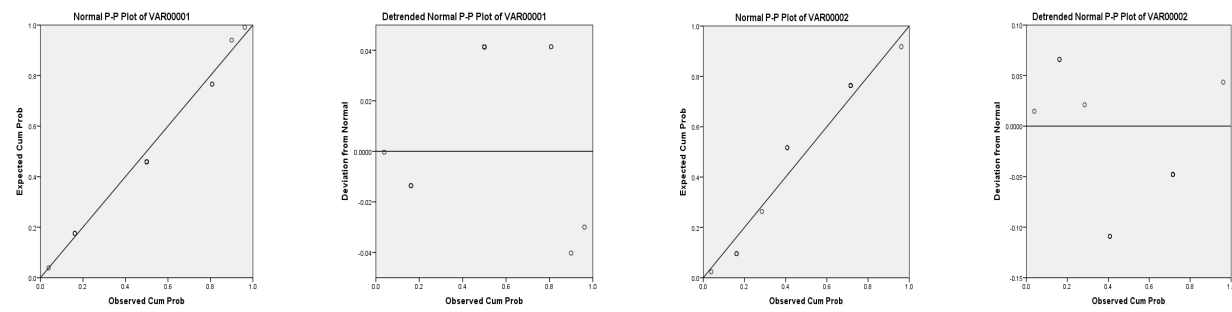

Figure 1. Normal distribution of data

The analytical results of the paired t-test (two-tailed) reveal that the difference between the pretest of the control group and that of the experimental group is not statistically significant at the .05 level (see Table 5).

Table 5. Paired T-Test (2-tailed)

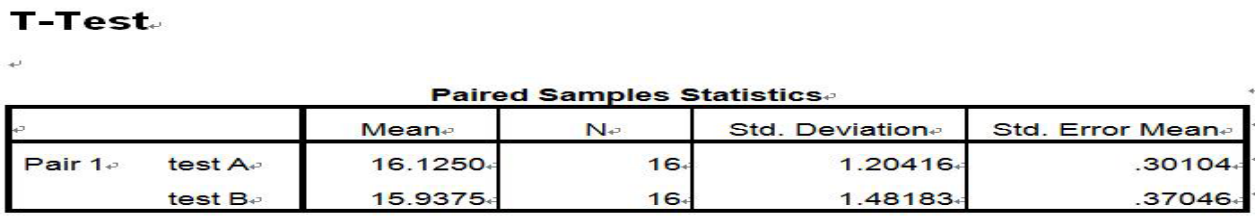

Paired Samples Correlations

\begin{tabular}{|lr|r|r|r|}
\hline & $\mathrm{N}$ & Correlation & \multicolumn{1}{c|}{ Sig. } \\
\hline Pair 1 & test A \& test B & 16 & .715 & .002 \\
\hline
\end{tabular}

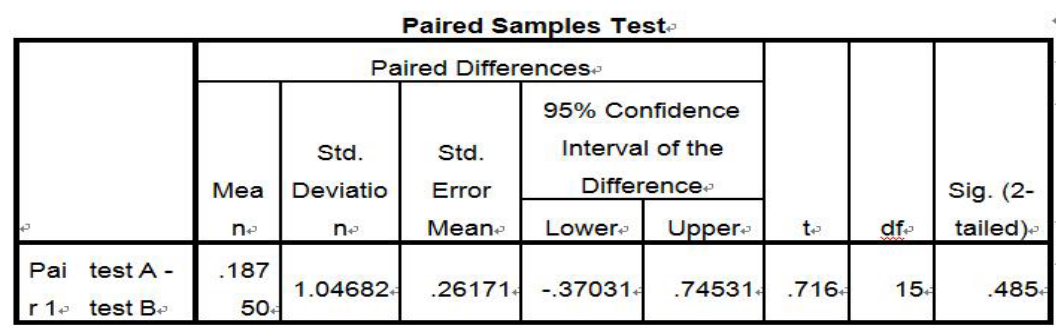

The lexical ability of the control group and the experimental group are at a similar level before instruction using conventional lexical teaching methods and the pedagogical application of corpus in lexical teaching. The two groups are immersed in two different lexical teaching programs for approximately four months. All the participants in the two groups complete the posttest afterwards. The results are again collected and analyzed by SPSS 24. The normal distribution of data is shown in the following figures.
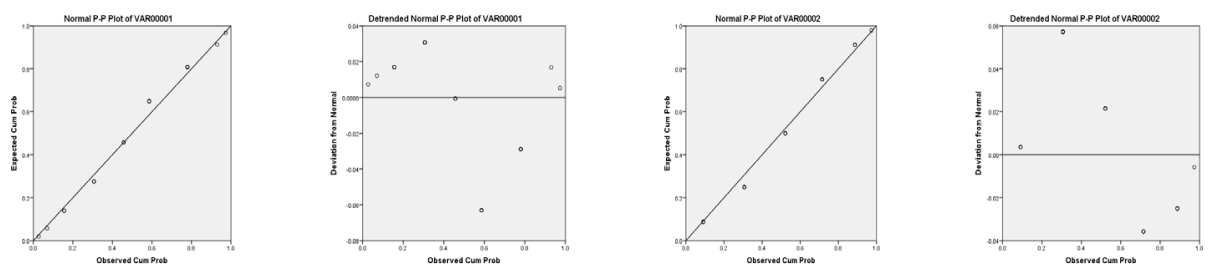

Figure 2. Normal distribution of data (control group) 

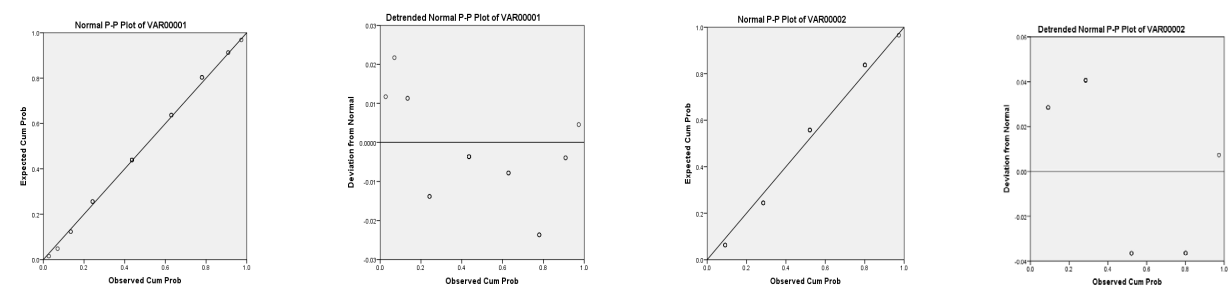

Figure 3. Normal distribution of data (experimental group)

The analytical results of the independent samples t-test (two-detailed) reveal that the difference between the performances of two groups is statistically significant at the .05 level (see Table 6). In general, the experimental group outperformed the control group.

Table 6. Independent Samples t-test (2-tailed)

\begin{tabular}{|c|c|c|c|c|c|}
\hline \multicolumn{6}{|c|}{ Group Statistics } \\
\hline 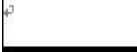 & b1_b2 & $\mathrm{N}$ & Mean & Std. Deviation & Std. Error Mean \\
\hline \multirow[t]{2}{*}{ gezichayi } & 1.00 & 23. & -1.5217 & 2.37160 & .49451 \\
\hline & 2.00 & 23. & -.7826 & 2.77909 & .57948 \\
\hline \multicolumn{6}{|c|}{ Group Statistics } \\
\hline 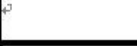 & b1_b2 & $\mathrm{N}$ & Mean & Std. Deviation & Std. Error Mean \\
\hline \multirow[t]{2}{*}{ gezichayi } & 1.00 & 23. & -1.5217 & 2.37160 & .49451 \\
\hline & 2.00 & 23. & -.7826 & 2.77909 & .57948 \\
\hline
\end{tabular}

Therefore, Hypothesis H1, that the experimental group would outperform the control group in vocabulary ability, is supported by the statistical data. The pedagogical application of a corpus with adequate instruction is more effective in improving learners' vocabulary ability. Afterwards, open-ended interviews are conducted by the researcher. Participants in the experimental group, in general, are satisfied with the innovative approach of lexical teaching.

\section{Participant A:}

At the very beginning, we felt a little intimidated by the new approach as we had no idea about corpora. However, the researcher gave us training on the corpus-based search engine. It is user-friendly and we could get a large quantity of authentic language materials that we could use in our daily life.

\section{Participant B:}

During the lexical teaching and learning process, we could acquire the language by "doing it". As the Chinese saying goes, tell me, I will forget; show me, I may remember; involve me, I will understand. We were immersed in a lot of language materials and did some experiments with them.

\section{Participant $C$ :}

We used to get bored with lexical teaching and learning and could not help dozing off once the lecturer started teaching us. But the new teaching method, on the other hand, could easily get us involved. In general, we were satisfied with the method, but some of the language materials are quite challenging for us and the materials need improvement.

The results of the open-ended interview triangulate the positive effects of pedagogical application of corpus on the lexical learning of intermediate-level ESL learners. In general, participants in the experimental group find the innovative method interesting and useful but note that it still needs improvement.

\section{Conclusions}

This research reports on the effects of the pedagogical application of corpora on intermediate-level ESL learners in mainland China. The new-GSL is applied in the lexical teaching process and research. A pretest and posttest 
were conducted and open-ended interviews were conducted and the statistics were then analyzed. Findings indicate that the pedagogical application of a corpus with adequate instruction is suitable for improving learners' vocabulary. However, this research was conducted during a period of only four months, and more longitudinal research is needed into the positive effects of the pedagogical application of corpora on lexical teaching and learning. This would serve to satisfy the requirements for educating ESL learners in the Chinese context while enabling them to be more informed, curious, and critical in their English lexical learning.

\section{Acknowledgments}

This article is sponsored by the research project (Project Code: GD15WZ06), supported by the Guangdong Planning Office of Philosophy and Social Science.

\section{References}

Angouri, J. (2010). Quantitative, qualitative or both? Combining methods in linguistic research. In L. Litosseliti (Ed.), Research methods in linguistics (pp. 29-45). London, England: Continuum.

Barkley, E. F. (2009). Student engagement techniques: A handbook for college faculty. New York, NY: Jossey-Bass Wiley.

Bernardini, S. (2002). Exploring new directions for discovery learning. In B. Kettemann, \& G. Marco (Eds.), Teaching and learning by doing corpus analysis (pp. 165-182). Amsterdam, Holland: Rodopi. https://doi.org/10.1163/9789004334236_015

Brezina, V., McEnery, T., \& Wattam, S. (2015). Collocations in context: A new perspective on collocation networks. International Journal of Corpus Linguistics, 20(2), 139-173. https://doi.org/10.1075/ijcl.20.2.01bre

Cheng, W., Warren, M., \& Xu, X. F. (2003). The language learner as language researcher: Putting corpus linguistics on the timetable. System, 31, 173-186. https://doi.org/10.1016/S0346-251X(03)00019-8

Cobb, T. (1997). Is there any measureable learning from hands-on concordancing? System, 25, 301-315. https://doi.org/10.1016/S0346-251X(97)00024-9

Dornyei, Z. (2007). Research methods in applied linguistics: Quantitative, qualitative and mixed methodologies. Oxford, England: Oxford University Press.

Ellis, N. C., Simpson-Vlach, R., \& Maynard, C. (2008). Formulaic language in native and second language speakers: Psycholinguistics, corpus linguistics, and TESOL. TESOL Quarterly, 42, 375-396. https://doi.org/10.1002/j.1545-7249.2008.tb00137.x

Flowerdew, L. (2009). Applying corpus linguistics to pedagogy: A critical evaluation. International Journal of Corpus Linguistics, 14, 393-417. https://doi.org/10.1075/ijcl.14.3.05flo

Jiang, N. (2000). Lexical representation and development in a second language. Applied Linguistics, 21, 47-77. https://doi.org/10.1093/applin/21.1.47

Johns, T. (1991). Should you be persuaded: Two examples of data-driven learning In Classroom Concordancing, T. Johns, \& P. King, (Eds.). English Language Research Journal, 4, 1-16.

Kennedy, G. (2003). Amplifier collocations in the British National Corpus: Implications for English language teaching. TESOL Quarterly, 37, 467-487. https://doi.org/10.2307/3588400

Lewis, M. (2002). Implementing the lexical approach: Putting theory into practice. Boston, MA: Thomson Heinle.

Mackey, A., \& Gass, S. M. (2005). Second language research: Methodology and design. Mahwah, NJ: Lawrence Erlbaum Associates.

Rasinger, S. M. (2013). Quantitative research in linguistics: An introduction (2nd ed.). London, England: Bloomsbury Publishing Plc.

Romer, U. (2006). Pedagogical applications of corpora: Some reflections on the current scope and a wish list for future developments. Zeitschrift fur Anglistik und Amerikanistik, 54, 121-134. https://doi.org/10.1515/zaa-2006-0204

Romer, U. (2011). Corpus research applications in second language teaching. Annual Review of Applied Linguistics, 31, 205-225. https://doi.org/10.1017/S0267190511000055

Stubbs, M. (1996). Text and Corpus Analysis. Oxford, England: Blackwell. 
Thurstun, J., \& Candlin, C. N. (1998). Concordancing and the teaching of the vocabulary of academic English. English for Specific Purposes, 17, 267-280. https://doi.org/10.1016/S0889-4906(97)00013-6

\section{Appendix A}

\section{The Article for Pretest Adaptability: The Key to Success}

Research shows that retailers today need to quickly react to the unique demands of Internet savvy consumers by integrating their physical and online stores. The key to success in today's fast-changing retail landscape is being able to adapt quickly while offering an integrated shopping experience via online and offline platforms, according to a new report by global professional services company Accenture.

Shoppers worldwide, especially in China, are becoming increasingly Internet savvy, meaning that mobile accessibility has become a critical element of the customer experience. According to Accenture's research, 73 percent of Chinese consumers use their smartphones to browse for goods and services frequently while about 40 percent prefer to receive real-time promotional notifications and credit coupons via their smartphones.

In addition, 80 percent of customers have web-roomed or show-roomed within the last year. Web-rooming is the act of browsing items online before making a purchase in a physical store. Showrooming, on the other hand, refers to browsing products in a physical store before buying it online.

However, research has shown that there are only a few retailers that are able to provide such services for customers, with just 7 percent of shops in the world providing updated information of discounts and sales on products through mobile platforms. In China, there are only 4 percent of retailers - the global average is 28 percent - that are able to provide up-to-date stock status for consumers.

"Retailers must make every effort to improve their mobile commerce capabilities and keep up with consumers' expectations. To be an adaptive retailer, the experience needs to be seamless for consumers who expect mobile devices to ease the shopping experience, both online and in-store," said Yew Hong Koh, managing director, retail lead for Accenture Asia Pacific.

According to the report, smartphones are the preferred mobile device when it comes to making purchases across categories, and more shoppers have indicated an increase in their purchases via smartphones compared to tablets. Chinese consumers in particular prefer to make purchase on social platforms ( 74 percent) like WeChat and online shops (70 percent) like Taobao.com that offer door-to-door delivery service.

"I don't have time to go to stores to shop. Instead, I regularly browse goods and make purchases online using my mobile device as this is more convenient. Shopping online is also another way to relax and kill time," said Chen Yanqing, a senior manager at a foreign-invested company in Shanghai.

The report also revealed that while businesses are beginning to pay closer attention to consumers' online shopping demands, many are still not able to meet expectations in two key areas: in-store and seamless shopping experiences. An increasing number of consumers were found to be frustrated with the lack of visibility across the retail channel, especially when it comes to checking product availability. This year, 34 percent of Chinese shoppers, compared to 17 percent a year ago, indicated that being able to ascertain product availability prior to making a trip to the store would help to provide a more seamless shopping experience.

"Visibility across channels is becoming more important to Chinese consumers. However, less than 20 percent offer this capability. Retailers must begin to look at their businesses from the consumer's perspective and place digital at the very core of the customer experience if they want to succeed," said Koh.

(Word Count: 554 words) 


\section{Appendix B}

\section{The Article for Posttest Now, Shopaholics Double Up as Ali's Marketing Squad}

Meng Cui Yi spent almost $\$ 90,000$ at Alibaba's online mall in the past year. The 33-year-old restaurateur buys pretty much everything there - Burberry apparel, La Mer skincare products, furniture, groceries and more. After Alibaba's annual Singles Day sale last year, Meng's purchases were piled so high outside her Shanghai apartment her businessman husband could barely get in the door.

Meng's lavish spending habits earned her an invite to Alibaba Passport, or APass, an exclusive rewards program. APass is a mash-up of Facebook, Amazon Prime and the American Express Black Card. Its 100,000 members get the usual perks - deals, trips, personal service - but are also encouraged to join online communities of shopaholics who blog and talk up Ali baba.

Rolled out about two years ago, APass has helped Alibaba persuade the well-heeled shoppers trawling its Tmall and Taobao shopping emporiums to keep spending. That's crucial because Alibaba is struggling to maintain rapid-fire growth.

Just last week, Singles Day sales grew at half the pace they did the year before. Meanwhile, the company is trying to ward off growing competition from rivals like JD.com, which is starting to attract urban big-spenders. "Standing still is not an option because competitors are nipping at their heels," said Duncan Clark, founder of investment advisory firm BDA China and an early adviser to Alibaba. "It's very much worth their while to take care of the high rollers."

Like any premium rewards program, APass pushes exclusivity by setting a seemingly high bar for membership. To make the cut, a customer must drop more than $\$ 15,000$ a year on Alibaba's e-commerce sites, though the company says members typically spend more than $\$ 45,000$. Spending is just one criterion. Shoppers also receive a user score, based in part on the frequency and credibility of their interaction with other customers. The higher the score, the more likely they are to be invited to join APass.

"APass members love to share," said Hai Wang, Alibaba's head of customer experience and innovation. "Every day in our APass Members Zone, a lot of members are sharing their daily life stories, shopping tips and showing off their shopping lists. A good number of APass members are verified bloggers."

Meng is Alibaba's dream customer. "I talk to other APass members every day," she said.

"I never actually buy anything from physical stores unless I'm going out with friends or something."

Meng's loyalty got her invited to the inaugural APass annual meeting, one of 50 members selected. Held in May at Mandarin Oriental hotel in Shanghai, the splashy event included a buffet dinner, lucky draw and an awards presentation - at which Maserati was voted Most Beloved Brand. Chief Marketing Officer Chris Tung gave a speech.

Rewards buy loyalty and then are turned into marketing opportunities. In early September, Alibaba took 10 APass members on an all-expenses paid, nine-day vacation to Italy where they visited a Maserati factory, La Perla's flagship lingerie store and vineyards operated by vintner Mezzacorona. Portions of the all-expenses-paid trip were streamed live on the Tmall app and Youku Tudou, a video site Alibaba Chairman Jack Ma acquired last year. The company said the vineyard tour was viewed 400,000 times and boosted sales. Public displays of loyalty from its most elite customers also could help Alibaba buff its reputation.

(557 words) 


\section{Appendix C}

\section{Pretest Sheet}

1. Which of the following words are used in this article?
1) A. adaptability
B. flexibility
2) A. reply
B. react
3) A. requirement
B. demand
4) A. savvy
B. wisdom
5) A. fast-changing
B. rapidly-changing
6) A. profession
B. professional
7) A. accessibility
B. accessible
8) A. share
B. stock
9) A. buy
B. purchase
10) A. senior
B. junior

1-5)

6-10)

Choose the best translation for the words from the article.

1) integrated
A. 完整的
B. 全部的
C. 所有的
D. 部分的
2) critical
A. 关键的
B. 厉害的
C. 严重的
D. 批评的

3) browse
A. 观察
B. 汶览
C. 巡视
D. 鸟瞰

4) capabilities
A. 能力
B. 品质
C. 销量
D. 容量

5) seamless
A. 流畅的
B. 一流的
C. 无缝的
D. 衔接起来的

6) delivery
A. 传递
B. 快递
C. 运输
D. 传输

7) channel
A. 途径
B. 渠道
C. 方式
D. 模式

8) ascertain
A. 指出
B. 暗示
C. 提示
D. 确定

9) perspective
A. 角度
B. 方位
C. 方向
D. 立场
10) prior to
A. 在...之后
B. 优于...
C. 比...差
D. 在...之前

1-5)

6-10)

Key:
1. 1-5) A B B A A
6-10) B A B B A
2. 1-5) A A B C C
6-10) B B D A D 


\section{Appendix D}

\section{Posttest Sheet}

1. Which of the following words are used in this article?
1) A. reception
B. reputation
2) A. inaugural
B. inauguration
3) A. frequency
B. frequent
4) A. furniture
B. fortune
5) A. shopaholic
B. alcoholic
6) A. barely
B. nearly
7) A. luxurious
B. lavish
8) A. exclusive
B. excluding
9) A. advisory
B. advising
10) A. premium
B. prime

1-5)

6-10)

Choose the best translation for the words from the article.

1) annual
A. 每年的
B. 每个月的
C. 每天的
D. 每个季度的

2) mash-up
A. 组合
B. 融合
C. 集锦
D. 配合

3) perk
A. 举高
B. 奖励
C. 提升
D. 拔高

4) emporium
A. 商业中心
B. 运动场
C. 艺术中心
D. 大剧院

5) ward off
A. 抵挡
B. 脱离
C. 合作
D. 协助

6) crucial
A. 关键的
B. 不重要的
C. 被遗忘的
D. 被忽视的

7) credibility
A. 学分
B. 信用
C. 认证
D. 信用卡

8) loyalty
A. 顺从
B. 服从
C. 忠诚
D. 老实

9) boost
A. 减少
B. 提升
C. 后退
D. 前进

10) rival
A. 合作者
B. 竞争对手
C. 敌人
D. 协助者

1-5)

6-10)

Keys:
1. 1-5) B A A A A
6-10) А B A A A
2. 1-5) A C B A A
6-10) A B C B B 


\section{Appendix E}

\section{Consent to Participate in Research}

Project Name: The Pedagogical Application of Corpus in Lexical Teaching

Investigator: Jing SHI

Mobile phone number: 13724063922

Email: sj@oamail.gdufs.edu.cn

Introduction

You are invited to consider participating in this research study. I will be evaluating the effect of carrying out different activities on learning English as a foreign language (EFL). This form will describe the purpose and nature of the study and your rights as a participant in the study. The decision to participate or not is yours. If you decide to participate, please sign and date the last line of this form.

Explanation of the study

The study attempts to analyze the effects of pedagogical processing of corpora on the short-term enhancement of lexical noticing ability by Chinese ESL learners. Participants will provide some bio-data and participate in relevant activities. You are going to take a test at the beginning, during the preliminary stage, and at the end of the study.

Confidentiality

All of the information collected will be confidential and will be used only for research. This means that your identity will remain anonymous; in other words, no one besides the researcher will know your name. Whenever data from this study are published, your name will not be used. The data will be stored in a computer, and only the researcher will have access to it.

Your participation

Participating in this study is strictly voluntary. This means you do not have to be a part of the study. Your decision to participate will in no way affect your grade in any class. You will participate in the same activities, but nothing you say or do will be used as part of the data. If at any point you change your mind and no longer want to participate, you can tell your teacher. You will be paid for participating in this study. If you have any questions about the research, you can contact Jing SHI by phone at 1372406 3922, by email sj@oamail.gdufs.edu.cn, or in person at Jing's office.

\section{Investigator's statement}

I have fully explained this study to the student. I have discussed the activities and have answered all of the questions that the student asked. If necessary, I have translated key terms and concepts in this form and explained the orally.

Signature of investigator

Date

Student's consent

I have read the information provided in this Informed Consent Form. All my questions were answered to my satisfaction. I voluntarily agree to participate in this study.

Your signature

Date 


\section{Appendix F}

\section{Participants' Bio-data}

Age: 19 (ranging from 18-20)

Gender: control group -4 males, 11 females

experimental group - 3 males, 12 females

Years of learning English: 10 (ranging from 8 to 12 years)

Major: Business English

Score on the English test of the Entrance Exam: 132 (ranging from 126-140)

Travel to English-Speaking countries:

$$
\begin{aligned}
& \text { control group - } 0 \\
& \text { experimental group-2 }
\end{aligned}
$$

The samples were quite homogeneous, making it easy for the researcher to generalize the results, but also leading the research scope to be relatively narrow.

\section{Copyrights}

Copyright for this article is retained by the author(s), with first publication rights granted to the journal.

This is an open-access article distributed under the terms and conditions of the Creative Commons Attribution license (http://creativecommons.org/licenses/by/4.0/). 